\title{
Duplex-real time polymerase chain reaction assay for simultaneous analysis of pork and chicken in sausage products
}

\author{
${ }^{1,2}$ Dinurrosifa, R.S., ${ }^{1}$ Sismindari, ${ }^{1}$ Rumiyati, R. and ${ }^{1,3 *}$ Rohman, A. \\ ${ }^{1}$ Faculty of Pharmacy, Universitas Gadjah Mada, Yogyakarta 55281 Indonesia \\ ${ }^{2}$ Semarang College of Pharmaceutical Sciences, Jl. Letnand Jendral Sarwo Edi Wibowo, Semarang 50192 \\ Indonesia \\ ${ }^{3}$ Institute of Halal Industry and Systems (IHIS), Universitas Gadjah Mada, Yogyakarta 55281 Indonesia
}

\begin{abstract}
Article history:
Received: 27 October 2019

Received in revised form: 11

December 2019

Accepted: 14 December 2019

Available Online: 30 June 2020
\end{abstract}

Keywords:

Sausage,

Pork,

Chicken,

Duplex analysis,

Real-time PCR

DOI:

https://doi.org/10.26656/fr.2017.4(5).356

\begin{abstract}
The adulteration of meat-based food is common due to the price difference among raw meat materials. One of the favorite foods commonly consumed by Indonesian and Malaysian societies is chicken sausage, which can be substituted by pork to get economical profits. The objective of this study was to develop a duplex real-time PCR assay using the EvaGreen fluorescence dye for the identification of chicken and pork in sausage products. The method involved the application of chicken (Gallus gallus) and pork (Sus scrofa) specific primers which amplify the small fragments (pork $176 \mathrm{bp}$ and chicken $183 \mathrm{bp}$ ) of the mitochondrial D-loop 22 and mt-12s rRNA genes, respectively. DNA was isolated from raw meat materials and reference sausage made from the mixtures of chicken and pork to optimize the assay. The primers used for pork were forward 5'TCG TAT GCA AAC CAA AAC GCC -3' and reverse: 5'- ATG CAT GGG GAC TAG CAG TTA -3', while primers used for chicken were forward: 5' TGA GAA CTA CGA GCA CAA AC 3' and reverse: 5' ACA TTG TGG GAT CTT CTA GGT 3'. Gene products of chicken and pork produced two distinct melting peaks simultaneously at 76.5 and $84.5^{\circ} \mathrm{C}$, respectively. The detection limit of duplex-real time PCR analysis of the reference sausage samples was $0.5 \%$ for pork and chicken meat in sausage products. The coefficient of variation $(\mathrm{CV})$ of threshold cycles $(\mathrm{Ct})$ for amplification was $6.25 \%$, lower than that required by the Codex Alimentarius Commission. Duplex-real time PCR analysis followed by melting curve analysis offered rapid, sensitive, and specific detection of pork and chicken in sausage products.
\end{abstract}

\section{Introduction}

Chicken sausages are one of the commonly consumed meat-based products worldwide. Due to the price difference among raw meat materials, some unethical sellers try to substitute chicken with pork (Kitpipit et al., 2014). Since the scandal horse meat adulteration in 2013, the authentication analysis of meatbased food products is fast growing field having relevance to religious due to the restriction of certain meat such as pork for Muslim and Jew communities (Ali et al., 2014), health aspects such as bovine Spongiform Encephalopathies (BSEs) diseases due to bovine consumption (Salman et al., 2012), fair-trade policy (Bottero and Dalmasso, 2011), and cultural-related issues (Haider et al., 2012).

The possibility of pork is used as a mixture of sausage formulation has been the main concern for the
Islamic followers, therefore, it is necessary to develop a specific and selective method of identifying pork in food products (Kesmen et al., 2007; Soares et al., 2013). Several methods have been developed for the detection of pork adulteration in food products such as meatballs and sausages, namely FTIR spectroscopy combined with multivariate data analysis (Rohman et al., 2011), nuclear magnetic resonance (Nurrulhidayah et al., 2015), the combination of electronic nose and gas chromatographymass spectrometry (Nurjuliana et al., 2011), differential scanning calorimetry (Mansor et al., 2012), twodimensional gas chromatography-mass spectrometry time of flight (Indrasti et al., 2010), and liquid chromatography (Rohman et al., 2012). Some of these methods are lack in sensitivity such as FTIR spectroscopy and complex instrumentation like NMR spectroscopy and 2D chromatography, therefore, specific method based on the DNA detection using real-time polymerase reaction has emerged as method of choice 
for detection of pork in food systems (Aida et al., 2005; Che Man et al., 2007).

Duplex-real time PCR analysis and other multiplex assay offered fast, sensitive, specific, and cost-effective techniques for the detection of animal species in food products based on the amplification of specific primers on DNA targets (Safdar et al., 2012; Motalib Hossain et al., 2017). This technique has been successfully used for detection of pork adulteration in bovine-based food (Soares et al., 2010), discrimination of DNA raw meats of bovine, buffalo and porcine in food chain for halal authentication (Hossain et al., 2017), identification of non-halal meats of pork, canine, rat, cat, and monkey (Ali et al., 2015), identification of beef, pork, horse and sheep species (Koppel et al., 2011), identification of beef, pork, lamb, chicken, ostrich, and horse meat (Kitpipit et al., 2014), and identification of DNA of seven meats namely beef, turkey, chicken, pork, horse meat, sheep and goat (Koppel et al., 2009). Identification of chicken DNA in a mixture of pigs, fish, and poultry in feed ingredients using chicken forward primers: 5'TGA GAA CGA GCA CAA AC 3' and reverse: 5'ACA TTG TGG GAT CTA GGT 3' has been successfully carried out by multiplex PCR (Dalmasso et al., 2004). The study used a PCR instrument, which requires the electrophoresis stage to determine the results of DNA amplification because each amplification cycle cannot be observed directly. Identification of pig DNA in a mixture of pork and chicken meatballs by real-time PCR method using primers targeting the mitochondria DNA (mtDNA) D-Loop22 has been successfully designed by Rohman et al. (2017). The real-time PCR method can be quantified specifically, and without requiring further stages. The real-time PCR method is done in one stage, to reduce the possibility of error or loss of sample and sample contamination during the transfer process. The method that has been developed is a testing method that identifies one type of meat in a single test (singleplex), so it has not been able to identify simultaneously which meat mixture is contained in the food sample. For this reason, it is necessary to develop a method that can identify two or more types of meat in one test without further stages that can identify more than one pair of primers, namely the multiplex real-time PCR.

However, no duplex-real time PCR assay has been reported for the differentiation of heavily consumed meats in sausage products, namely pork and chicken. Therefore, the objective of this study was to develop reliable and cost-saving duplex-real time PCR assay for identification of DNAs of pork and chicken simultaneously targeting two different genes in mitochondrial sites.

\section{Materials and methods}

\subsection{Materials}

The raw meats used in this study namely pork, chicken, beef and others are purchased from local markets around Yogyakarta, Indonesia. Preparation of chicken sausages was carried out according to Pebriana et al. (2017). The reference of $100 \%$ chicken sausage, $100 \%$ pork sausage and the mixture of pork-chicken sausages were prepared in the laboratory. Minced porkchicken meat was mixed with tapioca flour, egg, and spices (garlic, pepper, salt, and sugar). The meat and other ingredients were transferred into sausage casings before being boiled in water for $15 \mathrm{~min}$. The sausages were then stored at $-20^{\circ} \mathrm{C}$ before being used for analysis.

\subsection{Oligonucleotide primers}

The set of primers specific for pig species was designed by Rohman et al. (2017), while primers designed by Dalmasso et al. (2004) were used for amplification of chicken DNA (Table 1).

Table 1. set of primers used for analysis of chicken DNA and pig DNA

\begin{tabular}{clc}
\hline Species & \multicolumn{1}{c}{ Forward primer } & \multicolumn{1}{c}{ Reversed primer } \\
\hline \multirow{2}{*}{ Pig } & 5'- TCG TAT GCA AAC 5'- ATG CAT GGG GAC \\
& CAA AAC GCC -3' & TAG CAG TTA -3' \\
5' TGA GAA CTA CGA & 5' ACA TTG TGG GAT \\
Chicken & GCA CAA AC 3' & CTT CTA GGT 3' \\
\hline
\end{tabular}

\subsection{DNA Isolation}

The procedure of DNA isolation in sausage and fresh meat was carried out according to Sambrook et al. (1989). Each fresh meat as well as laboratory-made and commercial sausages were cut into small and were grounded with mortar and stamper. A-200 mg of grounded samples was added with $1000 \mu \mathrm{L}$ of lysis buffer comprising Tris $\mathrm{HCl}$, EDTA, $\mathrm{NaCl}$, and SDS $1 \%$, added with $30 \mu \mathrm{L}$ proteinase $\mathrm{K}(20 \mathrm{mg} / \mathrm{mL})$ and then vortexed for 5 mins. The mixture was incubated at $55^{\circ} \mathrm{C}$ for $1 \mathrm{hrs}$, and then centrifugated at $13.000 \mathrm{rpm}$ for 15 mins. In a new microtube, the supernatant was added with cold phenol ( $0.5 \mathrm{x}$ volume), shaken for $30 \mathrm{mins}$ with shaker, and followed by centrifugation at 13.000 rpm for 10 mins. The supernatant was transferred into a new micro-tube, added with chloroform ( $0.5 \mathrm{x}$ volume), homogenized, and centrifugated at $13.000 \mathrm{rpm}$ for 10 mins. The supernatant in a new micro-tube was taken, added with Na-acetate $3 \mathrm{M}$ pH $5.2(0.1 \mathrm{x}$ volume $)$ and absolute ethanol ( $2 \mathrm{x}$ volume), and incubated at $-4^{\circ} \mathrm{C}$ overnight. The pellet containing DNA was subsequently washed with $250 \mu \mathrm{L}$ ethanol $70 \%$, and dissolved in 50 $\mu \mathrm{L}$ TE buffer. DNA obtained was stored at $-20^{\circ} \mathrm{C}$ for further analysis. 


\subsection{Analysis using multiplex real-time PCR}

Analysis using real-time PCR was carried out with instrument of PCR CFX96 (Bio-Rad, USA) using total volume of $10 \mu \mathrm{L}$, which consisted of consisting of $5 \mu \mathrm{L}$ SsoFast EvaGreen Supermix (Bio-Rad, Hercules, CA, USA), $0.5 \mu \mathrm{L}$ forward primer of pig $5 \mu \mathrm{M}, 0.5 \mu \mathrm{L}$ reverse primer of pig $5 \mu \mathrm{M}, 0.5 \mu \mathrm{L}$ forward primer of chicken $5 \mu \mathrm{M}, 0.5 \mu \mathrm{L}$ reverse primer of chicken $5 \mu \mathrm{M}$, $0.5 \mu \mathrm{L}$ mixed DNA pork-chicken $(145.65 \mathrm{ng} / \mu \mathrm{L})$, and $2.5 \mu \mathrm{L}$ nuclease free water. The thermocycler of PCR was programmed as follows: pre-denaturation at $95^{\circ} \mathrm{C}$ for $30 \mathrm{~s}$, followed by 40 cycles of denaturation at $95^{\circ} \mathrm{C}$ for $15 \mathrm{~s}$, annealing temperature was optimized at 50 $60^{\circ} \mathrm{C}$ for $30 \mathrm{~s}$ based on $\mathrm{Tm}$ of primer, and elongation at $72^{\circ} \mathrm{C}$ for $10 \mathrm{~s}$.

\subsection{Validation of real-time PCR}

Validation of real-time PCR analysis was carried out by assessing numerous characteristics performances including the sensitivity expressed with detection limit, efficiency and precision. The validated method was subsequently used for the analysis of commercial sausage.

\section{Results and discussion}

Duplex-real time PCR using two primers specific to species of Sus scrofa (pig) and Gallus gallus (chicken) targeting on the mitochondrial D-loop 22 and mt-12s rRNA genes was developed for identification of chicken sausages adulterated with pork for halal authentication study. DNA was obtained from the isolation of fresh tissue of raw meats or sausage samples containing pork and chicken using chloroform-phenol-isoamyl alcohol according to Sambrook et al. (1989). The DNA isolates obtained were analyzed qualitatively using $0.8 \%$ agarose gel electrophoresis. The purity of DNA isolates and quantitative analysis was performed using a UV spectrophotometer at a wavelength $(\lambda)$ of 260 and $\lambda 280$ $\mathrm{nm}$. Gel electrophoresis was used to verify the DNA integrity since the variations of DNA fragment length which used as the parameter for DNA integrity are dependent on samples analyzed, the extensive degree of food processing and the DNA extraction method.

Figure 1 reveals the DNA profiles extracted from raw materials of meat [A] and those extracted from chicken-pork sausages [B], in which the DNAs extracted from reference sausages showed intense smears of short and long DNA molecules, which indicated that DNA was not degraded excessively during extraction (Mafra et al., 2008). The ratio of absorbance values at $260 \mathrm{~nm}$ and $280 \mathrm{~nm}\left(\mathrm{~A}_{260} / \mathrm{A}_{280}\right)$ was between 1.7 and 1.97 for all extracted DNAs, therefore, this extraction procedure ensured that good quality DNA was obtained from all
[A]

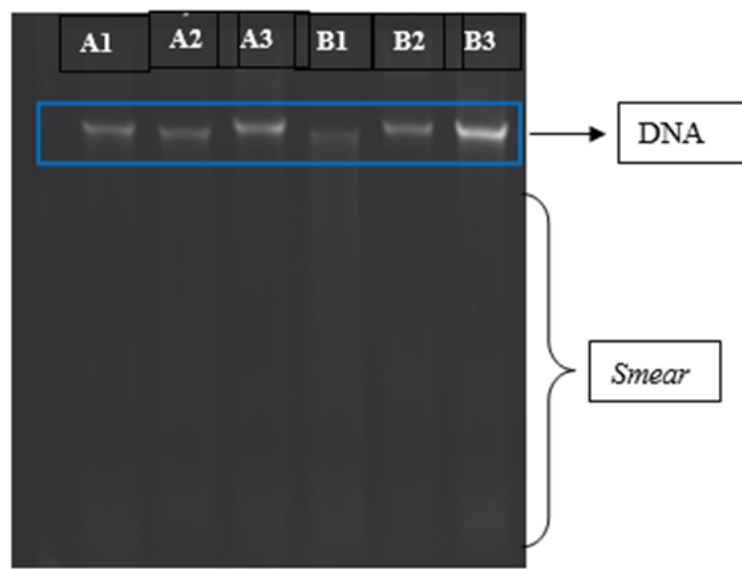

[B]

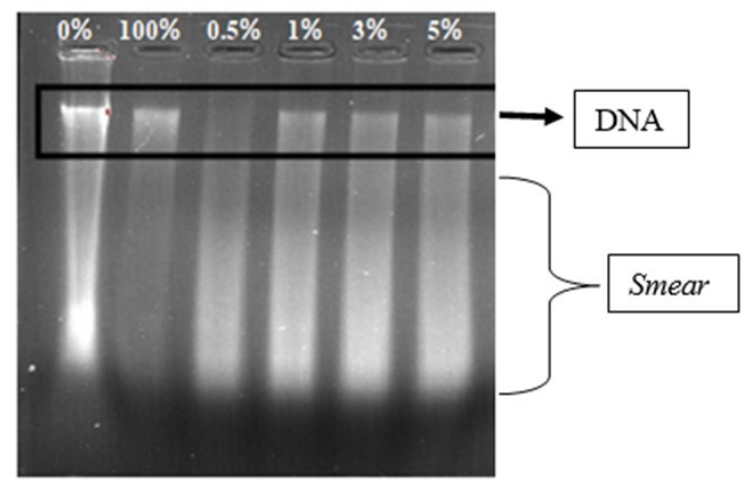

Figure 1. The agarose gel electrophoresis of DNAs extracted from raw meats of chicken (A1, A2, A3) and pork (B1, B2, B3) $[\mathrm{A}]$ and DNAs extracted from sausages containing $0 \%$ chicken- $100 \%$ pork $(0 \%), 100 \%$ chicken- $0 \%$ pork $(100 \%)$, $0.5 \%$ of pork- $99.5 \%$ chicken $(0.5 \%), 1 \%$ of pork- $99 \%$ chicken (1\%), $3 \%$ of pork- $97 \%$ chicken (1\%), and $5 \%$ of pork- $95 \%$ chicken $(5 \%)[\mathrm{B}]$.

samples and it was suitable for running of PCR reaction (Nejad et al., 2014).

The annealing temperature is subjected to optimization at the temperature range of $50-60^{\circ} \mathrm{C}$. At this temperature, DNAs extracted from pork and chicken were amplified to get the maximum response having the highest relative fluorescence unit (RFU) values with the lowest quantification cycle $(\mathrm{Cq})$ value. Figure 2 shows the amplification curve for the optimization of annealing temperature using primers specific for pig and chicken having annealing temperature of $59.40^{\circ} \mathrm{C}$. The amplification products of DNAs extracted from chicken and pork produced two distinct melting peaks simultaneously at 76.5 and $84.5^{\circ} \mathrm{C}$, respectively. There are no dimer primers and non-specific products observed. The optimum annealing temperature of a specific primer for both pig and chicken were of $59.40^{\circ} \mathrm{C}$, therefore, this temperature was used to perform duplex-real time PCR analysis. Things to consider in doing duplex real-time PCR mainly the temperature 
[A]

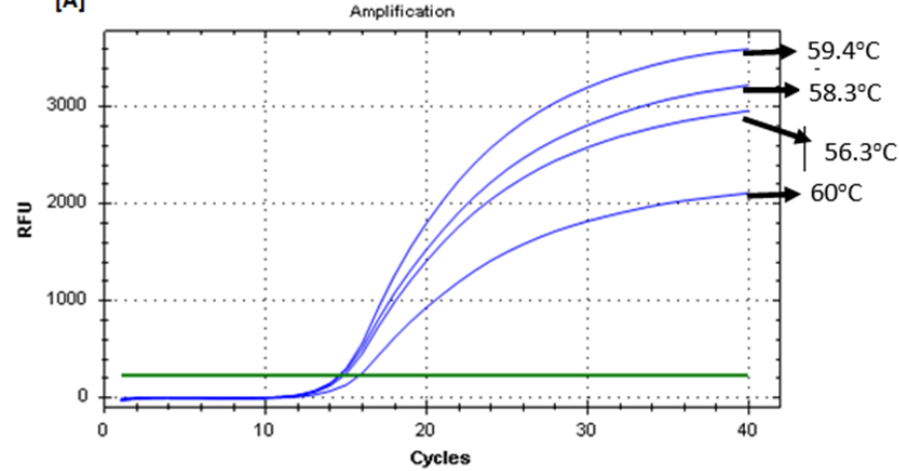

[B]

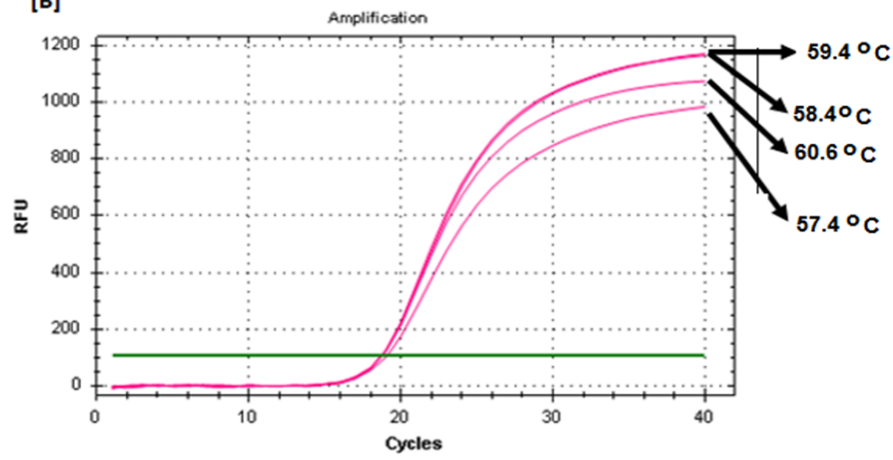

Figure 2. The amplification curve obtained during the optimization of annealing temperature using primers specific for pig [A] and chicken $[\mathrm{B}]$.

annealing, several pairs of primers designed must have the same annealing temperature as each other. The specificity of primers was tested for amplification of DNAs extracted from the reference sausages containing chicken and pork. The results of the duplex RT-PCR test for simultaneous detection of pig and chicken DNAs produced a single curve with two peaks having a melting temperature $(\mathrm{Tm})$ value of $75.50^{\circ} \mathrm{C}$ for pig and $84.00^{\circ} \mathrm{C}$ for chicken. This $\mathrm{Tm}$ difference could be used as the indicator for the presence of chicken meat and pork in sausage products. Figure 3 exhibits the melting curve analysis obtained during the amplification of pork and chicken DNAs using specific primers having a melting

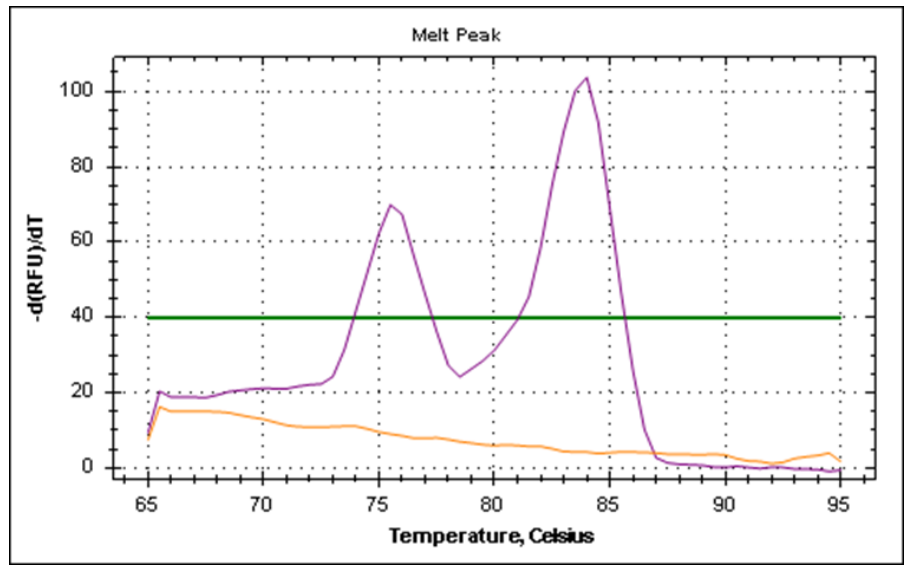

Figure 3. The melting curve analysis obtained during the amplification of pork and chicken DNAs using specific primers having a melting temperature $(\mathrm{Tm})$ value of $75.50^{\circ} \mathrm{C}$ for pig and $84.00^{\circ} \mathrm{C}$ for chicken.

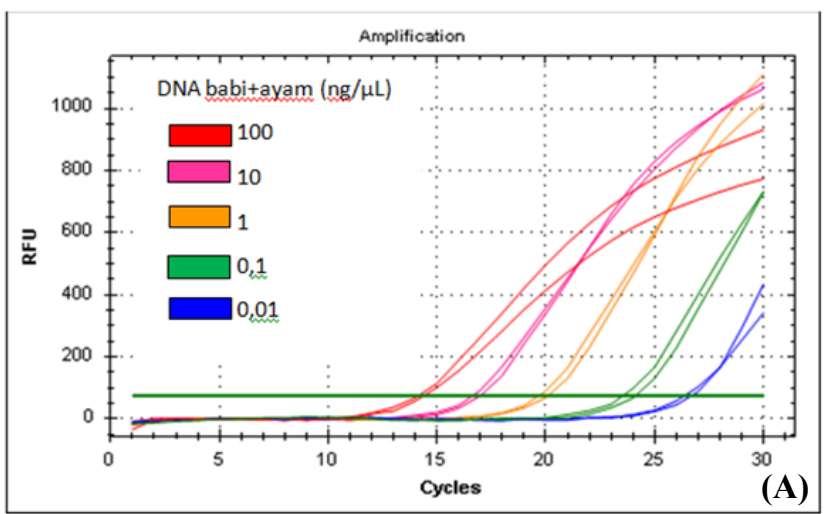

temperature $(\mathrm{Tm})$ value of $75.5^{\circ} \mathrm{C}$ for pig and $84.0^{\circ} \mathrm{C}$ for chicken.

The validation of duplex-real time PCR was performed by assessing the parameters of sensitivity expressed by the limit of detection (LoD) of DNAs extracted from chicken and pork, the repeatability test for precision evaluation, and the efficiency value (E) of amplification. During the evaluation of LoD, DNAs extracted from the mixture of raw meats of chicken and pork as well as DNAs extracted from reference sausages were subjected to serial dilutions to get $100 ; 10 ; 1 ; 0,1$; and $0.01 \mathrm{ng}$ (raw meats) and $0.5 ; 1 ; 3$; and $5 \%$ of pork. The primers could amplify DNAs of chicken meat and pork as low as of $0.01 \mathrm{ng}$ corresponding to $0.5 \%$ of meats in sausage samples (Figures 4 and 5). The $\mathrm{R}^{2}$ value obtained was 0.993 and 0,963 for reference sausages, which meet the requirements according to Codex Alimentarius commission (2010). The efficiency value obtained was $107.5 \%$ (acceptance criteria of 90 $105 \%$ ). The repeatability test showed that coefficient variation $(\mathrm{CV})$ was $6.25 \%$ which meets requirements for PCR assay, namely $\mathrm{CV} \leq 25 \%$ (Codex Allimentarius Commission, 2010). Analysis of pork DNA to chicken sausage samples did not indicate the presence of pork because there are no amplification peaks corresponding to pig DNA (Figure 6).

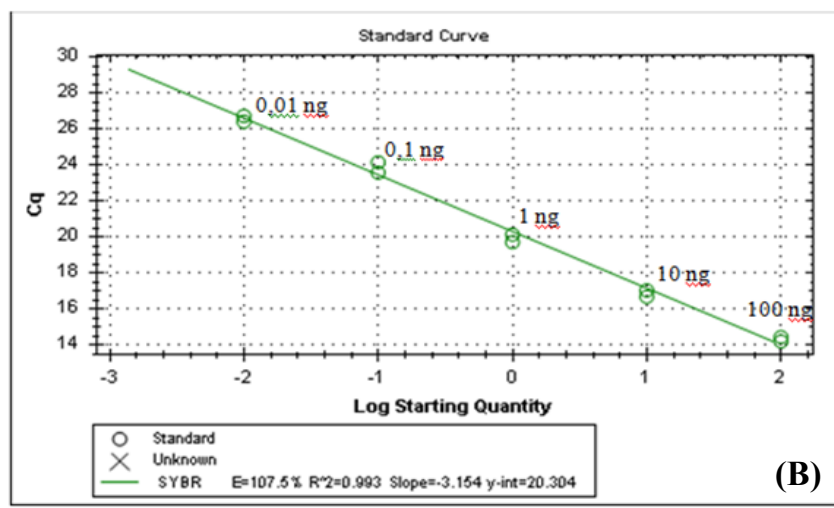

Figure 4. The sensitivity results of fresh DNA tissue dilution series of pigs: chicken with duplex-real time PCR with concentrations of pig and chicken DNAs concentration: chicken 100;10;1;0.1; and $0.01 \mathrm{ng}$. (A) amplification curve; (B) linear regression for determination efficiency value. 

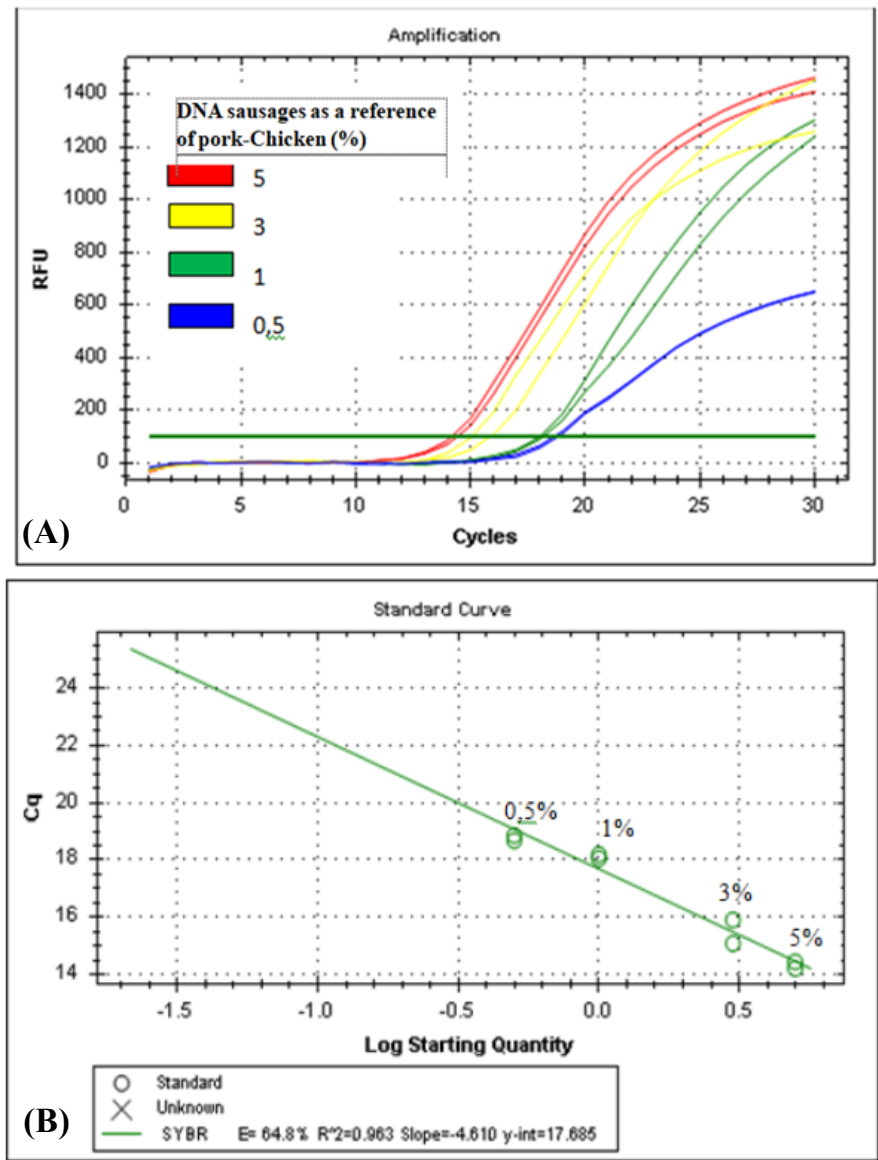

Figure 5. The sensitivity result of sausages as a reference of pork-chicken concentration 0,$5 ; 1 ; 3$; and $5 \%$. (A) amplification curve (B) linear regression for determination efficiency value

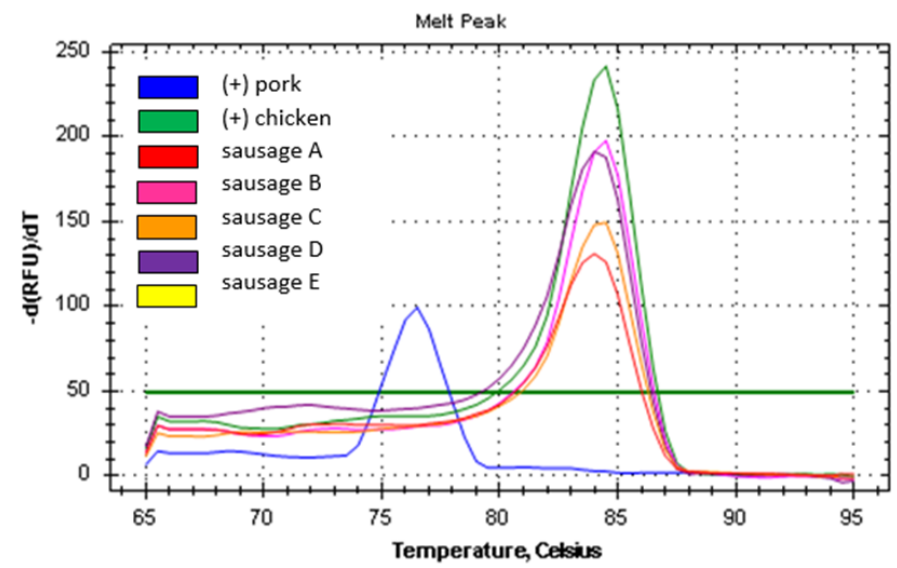

Figure 6. The amplification curves of DNA extracted from commercial samples of sausages. No amplification is found for all samples tested.

\section{Conclusion}

The method of duplex-real time PCR using speciesspecific primers can detect pork and chicken DNAs in chicken sausage products simultaneously. Detection limits on a mixture of DNA of fresh pork-chicken and pork-chickens mixed sausages were $0.01 \mathrm{ng}$ and $0.5 \%$, respectively. Duplex-real time PCR analysis followed by melting curve analysis offered rapid, sensitive, and specific detection of pork and chicken in sausage products and therefore could be proposed as standard method for meat species detection in meat-based food products for halal authentication.

\section{Acknowledgements}

The authors acknowledged to Faculty of Pharmacy, Universitas Gadjah Mada and the publication of this paper was supported by scheme World Class Research (WCR) 2020 from the Ministry of Research and Technology with contract number: 3848/UN1/DITLIT/ DIT-LIT/PT/2020

\section{References}

Aida, A.A., Che Man, Y.B., Wong, C.M.V.L., Raha, A.R. and Son, R. (2005). Analysis of raw meats and fats of pigs using polymerase chain reaction for Halal authentication. Meat Science, 69(1), 47-52. https://doi.org/10.1016/j.meatsci.2004.06.020

Ali, M.E., Rahman, M.M., Hamid, S.B.A., Mustafa, S. and Hashim, S.B.U. (2014). Canine-specific PCR assay targeting cytochrome $\mathrm{b}$ gene for the detection of dog meat adulteration in commercial frankfurters. Food Analytical Methods, 7, 234-241. https:// doi.org/10.1007/s12161-013-9672-y

Ali, M.E., Asing Hamid, S.B.A., Razzak, M.A., Rashid, N.R.A., Amin, M.A. and Mustafa, S. (2015). A suitable method to detect potential fraud of bringing Malayan box turtle (Cuora amboinensis) meat into the food chain. Food Additives and Contaminants: Part A, 35(8), 1-11. https:// doi.org/10.1080/19440049.2015.1058535

Bottero, M.T. and Dalmasso, A. (2011). Animal species identification in food products: Evolution of biomolecular methods. The Veterinary Journal, 190 (1), 34-38. https://doi.org/10.1016/j.tvj1.2010.09.024

Che Man, Y.B., Aida, A.A., Raha, A.R. and Son, R. (2007). Identification of pork derivatives in food products by species-specific polymerase chain reaction (PCR) for halal verification. Food Control, 18(7), $\quad$ 885-889. https://doi.org/10.1016/ j.foodcont.2006.05.004

Codex Alimentarius Commission (CAS). (2010). GL 74. Codex guidelines on performance criteria and validation of methods for detection, identification, and quantification of specific DNA sequences and specific proteins in foods.

Dalmasso, A., Fontanella, E., Piatti, P., Civera, T., Rosati, S. and Bottero, M.T. (2004). A multiplex PCR assay for the identification of animal species in feedstuffs. Molecular and Cellular Probes, 18(2), 81 -87. https://doi.org/10.1016/j.mcp.2003.09.006

Haider, N., Nabulsi, I. and Al-Safadi, B. (2012). 
Identification of meat species by PCRRFLP of the mitochondrial COI gene. Meat Science, 90(2), 490493. https://doi.org/10.1016/j.meatsci.2011.09.013

Indrasti, D., Che Man, Y.B., Mustafa, S. and Hashim, D.M. (2010). Lard Detection Based on Fatty Acids Profile Using Comprehensive Gas Chromatography Hyphenated with Time-of-Flight Mass Spectrometry. Food Chemistry, 122(4), 1273-1277. https:// doi.org/10.1016/j.foodchem.2010.03.082

Kesmen, Z., Sahin, F. and Yetim, H. (2007). PCR assay for the identification of animal species in cooked sausages. Meat Science, 77(4), 649-653. https:// doi.org/10.1016/j.meatsci.2007.05.018

Kitpipit, T., Sittichan, K. and Thanakiatkrai, P. (2014). Direct-multiplex PCR assay for meat species identification in food products. Food Chemistry, 163, 77-82. j.foodchem.2014.04.062

Koppel, R., Zimmerli, F. and Breitenmoser, A. (2009). Heptaplex real-time PCR for the identification and quantification of DNA from beef, pork, chicken, turkey, horse meat, sheep (mutton) and goat. European Food Research and Technology, 230, 125-133.

Koppel, R., Ruf, J. and Rentsch, J. (2011). Multiplex real -time PCR for the detection and quantification of DNA from beef, pork, horse and sheep. European Food Research and Technology, 232, 151-155. https://doi.org/10.1007/s00217-010-1371-y

Mafra, I., Ferreira, I.M.P.L.V.O. and Oliveira, M.B.P.P. (2008). Food authentication by PCR-based methods. European Food Research and Technology, 227(3), 649-665. https://doi.org/10.1007/s00217-007-0782-x

Mansor, T.S.T., Che Man, Y.B. and Shuhaimi, M. (2012). Employment of differential scanning calorimetry in detecting lard adulteration in virgin coconut oil. Journal of the American Oil Chemists' Society, 89(3), 485-496. https://doi.org/10.1007/ s11746-011-1936-3

Motalib Hossain, M.A., Ali, Md.A., Hamid, S.B.A., Asing, Mustafa, S., Desa, M.N.M. and Zaidul, I.S.M. (2017). Targeting double genes in multiplex PCR for discriminating bovine, buffalo and porcine materials in food chain. Food Control, 73(B), 175-184. https:// doi.org/10.1016/j.foodcont.2016.08.008

Nejad, F.P., Tafvizi, F., Ebrahimi, M.T. and Hosseni, S.E. (2014). Optimization of multiplex PCR for the identification of animal species using mitochondrial genes in sausages. European Food Research and Technology, 239, 533-541.

Nurjuliana, M., Che Man, Y.B., Mat Hashim, D. and Mohamed, A.K.S. (2011). Rapid identification of pork for halal authentication using the electronic nose and gas chromatography mass spectrometer with headspace analyzer. Meat Science, 88(4), 638644. https://doi.org/10.1016/j.meatsci.2011.02.022

Nurrulhidayah, A.F., Che Man, Y.B., Rohman, A., Rosman, A.S., Ismail, A., Mustafa, S. and Khatib, A. (2015). Detection of Butter Adulteration with Lard by Employing 1H-NMR Spectroscopy and Multivariate Data Analysis. Journal of Oleo Science, 64(7), 697-703. https://doi.org/10.5650/jos.ess 14255

Pebriana, R.B., Rohman, A., Lukitaningsih, E. and Sudjadi. (2017). Development of FTIR spectroscopy in combination with chemometrics for analysis of rat meat in beef sausage employing three lipid extraction systems. International Journal of Food Properties, 20(Suppl. 2), 1995-2005. https:// doi.org/10.1080/10942912.2017.1361969

Rohman, A., Himawati, A., Triyana, K., Sismindari, and Fatimah, S. (2017). Identification of pork in beef meatballs using Fourier transform infrared spectrophotometry and real-time polymerase chain reaction. International Journal of Food Properties, 20(3), 654-661. https:// doi.org/10.1080/10942912.2016.1174940

Rohman, A., Sismindari, Y., Erwanto, Y. and Che Man, Y.B. (2011). Analysis of pork adulteration in beef meatball using Fourier transform infrared (FTIR) spectroscopy. Meat Science, 88(1), 91-95. https:// doi.org/10.1016/j.meatsci.2010.12.007

Rohman, A., Triyana, K., Sismindari, and Erwanto, Y. (2012). Differentiation of lard and other animal fats based on triacylglycerols composition and principal component analysis. International Food Research Journal, 19, 475-479.

Safdar, M., Junejo, Y., Arman, K. and Abasıyanık, M.F. (2014). Rapid bovine and caprine species identification in ruminant feeds by duplex real-time PCR melting curve analysis using Evagreen fluorescence dye. Molecular Biotechnology, 56, 770 -776. https://doi.org/10.1007/s12033-014-9756-y

Salman, M., Silano, V., Heim, D. and Kreysa, J. (2012). Geographical BSE risk assessment and its impact on disease detection and dissemination. Preventive Veterinary Medicine, 105(4), 255-264. https:// doi.org/10.1016/j.prevetmed.2012.01.006

Sambrook, J., Fritsch, E.F. and Maniatis, T. (1989). Molecular Cloning: A Laboratory Manual. UK, England: Cold Spring Harbor Laboratory Press.

Soares, S., Amaral, J.S., Mafra, I. and Oliveira, M.B.P.P. (2010). Quantitative detection of poultry meat adulteration with pork by a duplex PCR assay. Meat Science, 85(3), 531-536. https://doi.org/10.1016/ j.meatsci.2010.03.001

Soares, S., Amaral, J.S., Oliveira, M.B.P.P. and Mafra, I. (2013). A SYBR Green real-time PCR assay to detect and quantify pork meat in processed poultry 